\title{
Chemokinetic Agents for Monocytes in Human Milk: Possible Role of Tumor Necrosis Factor- $\alpha$
}

\author{
AKRAM A. MUSHTAHA, FRANK C. SCHMALSTIEG, THOMAS K. HUGHES, JR, \\ SRINIVASAN RAJARAMAN, HELEN E. RUDLOFF, AND ARMOND S. GOLDMAN \\ Departments of Pediatrics [A.A.M., F.C.S., H.E.R., A.S.G.], Pathology [A.A.M., S.R.], Human Biological \\ Chemistry and Genetics [F.C.S., A.S.G.], and Microbiology [T.K.H., A.S.G.], The University of Texas Medical \\ Branch, Galveston, Texas 77550
}

\begin{abstract}
Human milk was found to contain chemokinetic agents for human blood monocytes. The chemokinetic agents were whey proteins that were inactivated by heating at $56^{\circ} \mathrm{C}$ for $20 \mathrm{~min}$ or treatment with trypsin. Three peaks of chemokinetic activity less than $60 \mathrm{kD}$ in size were found by gel filtration chromatography. The chemokinetic activity of each peak obtained by gel filtration was partially blocked by polyclonal rabbit antibodies to recombinant human tumor necrosis factor- $\alpha$ (TNF- $\alpha)$. TNF- $\alpha$, or a protein that immunologically cross-reacted with it, was also detected in human milk by blockage of the cytotoxicity of human milk by anti-TNF- $\alpha$. Such proteins or others that elicit the release of TNF- $\alpha$ from the target cells may be responsible for the enhanced motility of human milk macrophages, and it is possible that they may alter the immunologic or metabolic activities of the alimentary tract of the recipient infant. (Pediatr Res 25:629-633)
\end{abstract}

\section{Abbreviations}

HML, human milk leukocytes

HMM, human milk macrophages

MEME, minimum essential medium, Eagle-modified

PBML, peripheral blood mononuclear leukocytes

TNF- $\alpha$, tumor necrosis factor- $\alpha$

Neutrophils, macrophages, and lymphocytes are found in human milk during the first few months of lactation and the numbers of macrophages in milk are particularly high as compared to the numbers of monocytes in human blood $(1,2)$. HMM have been found to present antigens to $T$ lymphocytes (3); synthesize prostaglandin E2, lysozyme (4), and complement components, $\mathrm{C} 2$ and $\mathrm{C} 4$ (5); phagocytize microorganisms; produce toxic oxygen radicals; and kill ingested microorganisms (610). The role of these cells in the recipient infant remains, however, unclear. Certain in vitro studies indicate their in vivo actions may be different from their counterparts in human blood. Their ability to produce and release IL-1 in the resting state or after stimulation with lipopolysaccharides was much less than that of human blood monocytes (11). Furthermore, the adherence and directed movement of human milk macrophages are not increased by chemoattractant agents (12). This suggested that special populations of blood monocytes may be attracted to the

Received September 16, 1988; accepted November 16, 1988

Correspondence and reprint requests Armond S. Goldman, M.D., Department of Pediatrics, Division of Immunology and Allergy, Room C2-31 Child Health Center, The University of Texas Medical Branch, Galveston, TX 77550.

Supported by grants from Mead Johnson Nutritional Division and the National Institute of Child Health and Human Development (5 R01 HD 21049-02). mammary gland or that blood monocytes are modified in the mammary gland or by factors in human milk. Additional experimental observations supported those possibilities. In contrast to the lack of movement of neutrophils in human milk (12-14), it was discovered that HMM spontaneously moved more rapidly than blood monocytes in a three-dimensional, type I collagen matrix (15).

In this study, the genesis of the increased motility of human milk macrophages was investigated. We tested whether circulating systemic factors produced early in lactation, mammary gland tissue factors, or constituents in human milk up-regulated the motility of blood monocytes. The investigations revealed that human milk contains chemokinetic agents for blood monocytes and that one of those chemokinetic agents may be TNF- $\alpha$ or a protein that immunologically cross-reacts with it.

\section{MATERIALS AND METHODS}

Research subjects-leukocyte preparations. The use of human subjects in this research was approved by the Institutional Review Board of the Medical School. Donors were healthy adults or healthy women who delivered full-term, normal infants vaginally 2 to 3 days before the collections (16). Milk was collected into sterile polypropylene tubes by a low pressure electric pump (Egnell, Inc., Cary, IL). Unfractionated HML were prepared as follows. Human colostrum was diluted 1:4 in RMPI 1640 (Whittaker M.A. Bioproducts, Walkersville, MD) and centrifuged at $4000 \times \mathrm{g}$ for $10 \mathrm{~min}$ at $4^{\circ} \mathrm{C}$. The cellular pellets were then resuspended in RPMI 1640 to achieve a final concentration of 1 $\times 10^{7}$ leukocytes $/ \mathrm{ml}$. Heparinized venous blood was subjected to Ficoll-Hypaque (Sigma Chemical Co., St. Louis, MO) density gradients (17) to obtain mononuclear cell fractions (90\% mononuclear leukocytes) that were enriched for monocytes (20-25\% of total cells). Cell viability was tested by trypan blue exclusion. Monocytes/macrophages and neutrophils in blood or milk were identified by staining for non-specific esterase or myeloperoxidase, respectively (18).

Motility of cells in collagen gels. Type I collagen was prepared from rat tail tendons as previously described (19). Tendons were stripped and solubilized in $3 \%(\mathrm{v} / \mathrm{v})$ acetic acid at $4^{\circ} \mathrm{C}$ for 2 days. After removing insoluble material by centrifugation, the collagen was precipitated by the addition of an equal volume of $20 \%(\mathrm{w} / \mathrm{v}) \mathrm{NaCl}$. The precipitate was pelleted by centrifugation at $3000 \times \mathrm{g}$ for $1 \mathrm{~h}$, washed, and resuspended in $3 \%$ acetic acid to achieve a final concentration of $1.2 \mathrm{mg} / \mathrm{ml}$. Then the solution was exhaustively dialyzed against distilled water with a $\mathrm{pH}$ of 4.0. A total of $8 \mathrm{ml}$ of the collagen stock solution were mixed with $1 \mathrm{ml}$ of a solution of $\mathrm{NaHCO}_{3}(4 \%, \mathrm{w} / \mathrm{v})$ and $1 \mathrm{ml}$ of a $10-$ fold concentrated solution of MEME (Flow Laboratories, McLean, VA) to restore the $\mathrm{pH}$ and ionic strength to physiologic levels. This solution was mixed quickly, placed in wells $(50 \mu \mathrm{l} /$ 
well) of microtiter plates (Becton Dickinson, Oxnard, CA) and allowed to gel at $37^{\circ} \mathrm{C}$. Unfractionated HML $\left(4-6 \times 10^{5}\right.$ macrophages/25 $\mu$ l RPMI 1640), fractionated PBML (4-6 $\times 10^{5}$ monocytes/25 $\mu$ l RPMI 1640), similar numbers of PBML previously incubated for $3 \mathrm{~h}$ in colostrum or its fractions (see "Fractionation of human colostrum") or recombinant human TNF- $\alpha$ kindly supplied by Dr. Taysuro Nishihara, Suntory Ltd. Research Center, Osaka, Japan, were placed on top of each gel and incubated at $37^{\circ} \mathrm{C}$ in $5 \% \mathrm{CO}_{2}$. Motile leukocytes observed at $240 \mu \mathrm{M}$ from the top of the gel (e.g., the bottom of the gel) were counted at $6-9$ h by inverted phase microscopy (Diavert, Leitz, FRG).

The types of cells that invaded the collagen gels were identified by cytochemical (18) or immunoperoxidase methods. For immunoperoxidase stains, gels were quick-frozen in precooled isopentane and embedded in O.C.T. Compound (Tissue Tek, Miles Scientific, Naperville, IL). After the tops were discarded, the gels were sliced horizontally into serial $4-\mu$ sections, air dried for 60 $\mathrm{min}$ and fixed in cold acetone $\left(-20^{\circ} \mathrm{C}\right)$ for $10 \mathrm{~min}$. After rehydration, they were incubated with one of the following primary antibodies to human antigens: sheep anti-cathepsin B (20) or anti-cathepsin-G (21) (ICN Immunobiologicals, Lisle, IL); mouse monoclonal anti-CD3, anti-CD5, anti-leu 7 (Becton Dickinson, Mountain View, CA), (Ortho Diagnostic System, Inc., Raritan, NJ); or mouse monoclonal anti-Mac-1 prepared in our laboratory. The preparations were exposed to either biotinylated rabbit anti-sheep IgG (Vector Laboratories, Burlingame, CA) or biotinylated sheep anti-mouse $\mathrm{IgG}$ (Cooper Biomedicals, Westchester, PA) (1:80). Then the reactions with streptavidin, biotinylated peroxidase complex (Amersham, Arlington Heights, IL) (1:500) were visualized by adding diaminobenzadine and hydrogen peroxide.

Fractionation of human colostrum. The aqueous phase of human colostrum was separated from the lipid phase by centrifugation at $4000 \times \mathrm{g}$ for $10 \mathrm{~min}$ at $4^{\circ} \mathrm{C}$. Cells were excluded from the aqueous phase preparations by centrifuging them repeatedly at $300 \times \mathrm{g}$ for $5 \mathrm{~min}$. The preparations were acidified to $\mathrm{pH} 4.0$ with $\mathrm{HCl}$ and centrifuged at $4^{\circ} \mathrm{C}$ at $10,000 \times \mathrm{g}$ for $30 \mathrm{~min}$ to remove the caseins. The resultant acid soluble (whey) fraction was then reconstituted to the original volume and to $\mathrm{pH} 7.4$.

Acellular colostrum was fractionated by gel filtration chromatography. The specimens $(1.5 \mathrm{ml})$ were pumped onto Sephacryl 200 (Pharmacia Fine Chemicals, Piscataway, NJ) using a $1.5 \times 45 \mathrm{~cm}$ column with a flow rate of $60 \mathrm{ml} / \mathrm{h}$ and eluted with $50 \mathrm{mM}$ PBS, $\mathrm{pH}$ 7.3. Protein concentrations in the effluent fractions were monitored by OD at $280 \mathrm{~nm}$. Fractions $(5 \mathrm{ml})$ were collected and tested for their abilities to enhance movement of peripheral blood monocytes in collagen gels. Enhancement of motility was expressed as a ratio between the number of cells in stimulated preparations divided by the number of cells in unstimulated preparations that migrated to $240 \mu \mathrm{M}$ at 6-9 $\mathrm{h}$.

$S D S-P A G E$ : Western blotting. The presence of TNF- $\alpha$ in the whey protein fraction of human milk was investigated by using SDS-PAGE and Western blotting (22). Whey protein fractions were mixed with equal volumes of a non-reducing solution containing $13 \mathrm{mM}$ Tris (pH 6.8) SDS (4.6\%), and glycerol $(20 \%$, $\mathrm{w} / \mathrm{v}$ ) and boiled for $2 \mathrm{~min}$. In some specimens, 2-mercaptoethanol (5\%; Sigma Chemical Co., St. Louis, MO.) was added. Then, SDS-PAGE was performed using 7.5-15\% concentrations of polyacrylamide. Electrophoresis was carried out with a $20 \mathrm{~mA}$ current for $1 \mathrm{~h}$ and subsequently with a $30 \mathrm{~mA}$ current for 3.5 h. The SDS running buffer, $\mathrm{pH} 8.3$, consisted of Tris $(25 \mathrm{mM})$, glycine $(191 \mathrm{mM})$, and $\operatorname{SDS}(0.1 \%)$.

The polyacrylamide gel was soaked in a transfer buffer consisting of Tris $(25 \mathrm{mM})$, glycine $(192 \mathrm{mM})$, and $20 \%$ methanol for $1 \mathrm{~h}$. The proteins were transferred electrophoretically onto a nitrocellulose strip by using a current of $100 \mathrm{~mA}$ overnight and $200 \mathrm{~mA}$ for an additional hour. The nitrocellulose sheets were blocked with $3 \%$ periodate treated BSA in $10 \mathrm{mM}$ phosphate buffered saline for $1 \mathrm{~h}$. The sheets were rinsed and incubated for
$1 \mathrm{~h}$ with rabbit polyclonal antibodies to recombinant human TNF- $\alpha$ (1:250 in Tris-saline and $0.05 \%$ Tween) prepared according to a previously reported immunization schedule for generating antibodies to human IFN- $\gamma(23)$ or a second rabbit polyclonal antibody preparations to TNF- $\alpha$ that was obtained from a commercial source (Genzyme Corporation, Boston, MA). After washing, the preparation was incubated with goat antibodies to rabbit IgG conjugated to biotin $(1: 1500, \mathrm{v} / \mathrm{v})$ for $1 \mathrm{~h}$. The preparations were washed and incubated for $1 \mathrm{~h}$ with streptavidin conjugated with horseradish peroxidase (Calbiochem, La Jolla, $\mathrm{CA})$. The sheets were then washed and developed with 4-chloro1-napthol.

Cytotoxicity assays. Cytotoxicity assays with human milk preparations or recombinant human $\mathrm{TNF}^{-} \alpha$ were performed as previously described (24). Briefly, $5 \times 10^{4}$ murine L-929 cells (American Type Culture Collection, Rockville, MD) in MEME, $10 \%$ FBS, penicillin $(100 \mathrm{U})$, and streptomycin $(100 \mu \mathrm{g} / \mathrm{ml})$ were placed in each well of a 96-well microtiter plate (Costar, Cambridge, MA) and incubated at $37^{\circ} \mathrm{C}$ in an atmosphere of $4 \%$ $\mathrm{CO}_{2}$. The medium was decanted after $24 \mathrm{~h}$ and replaced with MEME containing actinomycin D $(5 \mu \mathrm{g} / \mathrm{ml})$. The cells were then exposed to either unfractionated or fractionated whey proteins or recombinant human TNF- $\alpha$. Negative controls for these experiments consisted of cells incubated only in the previously described medium. After $24 \mathrm{~h}$ of incubation or when the preparations exhibited maximal cytotoxicity, cells were stained with crystal violet $(1 \%)$ in methanol $(20 \%)$ and photographed.

Data presentation-statistical analyses. Group data concerning the number of cells that invaded $240 \mu \mathrm{M}$ into the collagen gels were expressed as the mean $\pm \mathrm{SD}$. Differences between the degree of movement of HMM and peripheral blood monocytes were tested by an unpaired Student's t-test, whereas the effects of acellular human colostrum, whey protein fractions, recombinant TNF- $\alpha$, or antibodies to human TNF- $\alpha$ or human IL-1 upon the rate of movement of blood monocytes were tested by a paired Student's $t$ test.

\section{RESULTS}

Motility of blood monocytes and human milk macrophages. Blood monocytes from nine healthy adults and from nine healthy women in the first 2 days postpartum were investigated. For purposes of this presentation only the comparison of monocytes from healthy adults and HMM were shown because the rate of migration of blood monocytes from these two groups of subjects was similar. HMM moved far more rapidly than blood monocytes (Fig. $1 \mathrm{~A}$ ).

Effect of human milk upon motility of blood monocytes. The number of motile blood monocytes from normal adults or from women 2 days postpartum increased about 3 - to 4 -fold after they were exposed to acellular, defatted human colostrum (Fig. 1B). Moreover, the rates of movement of blood mononuclear leukocytes treated in vitro with human milk and of HMM were very similar (Fig. 1B). The movement of blood mononuclear leukocytes was also enhanced by incubating those cells in human milk collected at 4-5 days or 1 mo of lactation (data not shown). The mononuclear blood leukocytes that invaded the gels after exposure to human milk were found to display markers for monocytes/macrophages (non-specific esterase, cathepsin B), but not for neutrophils (myeloperoxidase, cathepsin $\mathrm{G}$ ) or lymphocytes (CD3, CD5, Leu 7).

Physicochemical characteristics of chemokinetic agents in human milk. Chemokinetic activity for blood monocytes was detected in the whey proteins of milk (Fig. 2). The activity was abolished by treating the whey proteins with trypsin or heating them at $56^{\circ} \mathrm{C}$ for 20 min (Fig. 2). Concentrations of whey proteins as low as $2 \%$ significantly increased the number of blood monocytes that invaded the collagen gels.

The molecular size of the activators as estimated by centrifugation through dialysis membranes (Spectrum Medical Indus- 

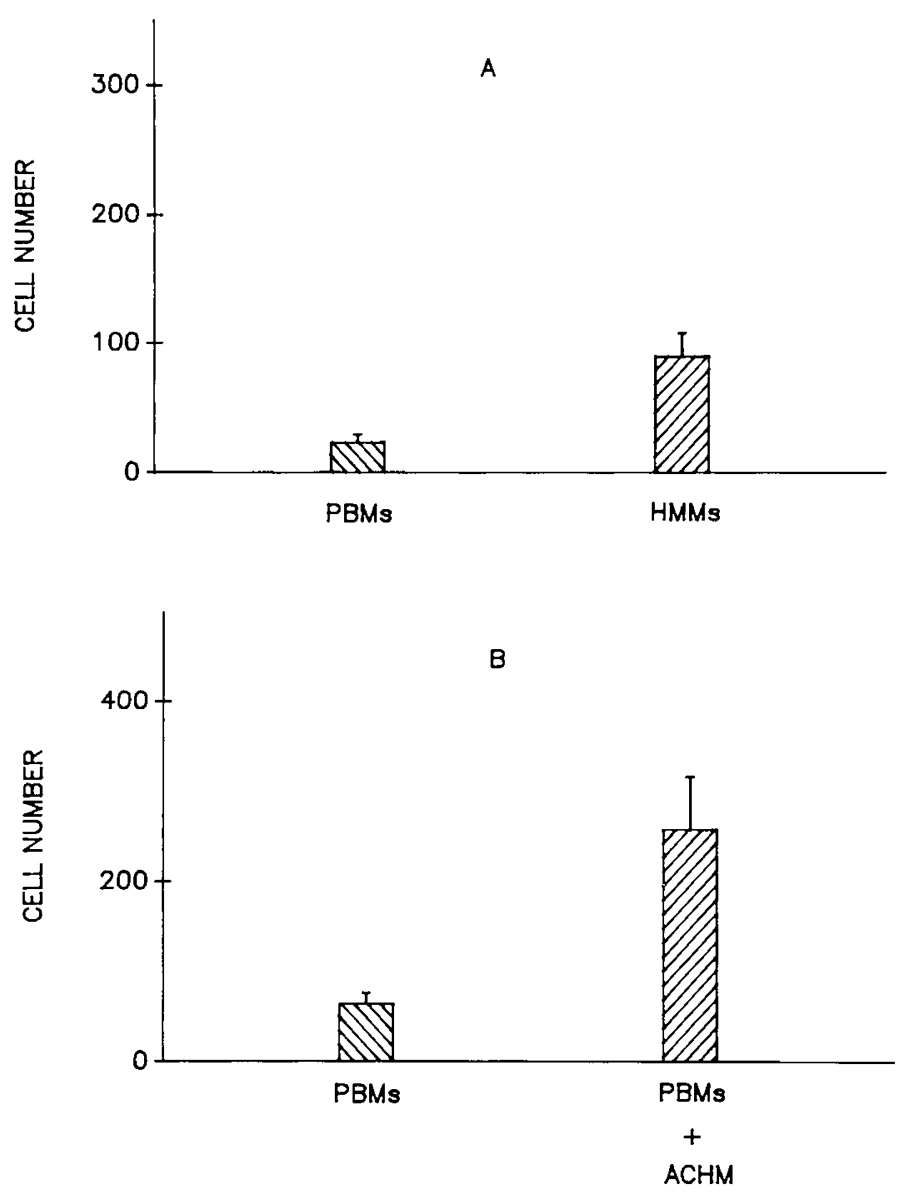

Fig. 1. Motility of HMM and untreated adult peripheral blood monocytes $P B M(A)$ and of adult or postpartum PBM incubated in acellular human milk $(A C H M)(B)$. Three separate sets of experiments were performed, and at least five studies were conducted for each set of experiments. Monocytes/macrophages were enumerated at $240 \mu \mathrm{M}$ after 6-9 h of incubation. Since there were no differences in the movement of unstimulated blood monocytes from adults or postpartum women, those data were pooled for this presentation. Furthermore, since the effects of $\mathrm{ACHM}$ upon blood monocytes from adults and postpartum women were also similar, those data were also combined. The motility of HMM was much greater than that of untreated PBM $(p<0.01)$, and the movement of PBM was significantly increased $(p<0.01)$ when they were incubated in ACHM. Because of variations in this experimental system over time, data from the two separate data sets were not compared.

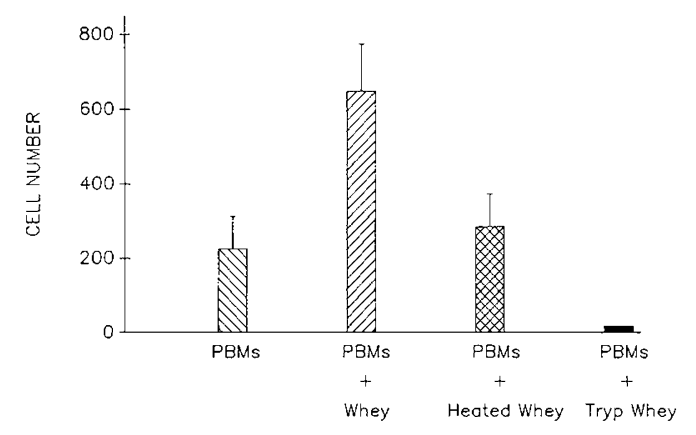

Fig. 2. The effects of heating $\left(56^{\circ} \mathrm{C}\right.$ for $\left.20 \mathrm{~min}\right)$ or trypsin (tryp) upon the chemokinetic properties of the whey protein fraction of human milk. Data were expressed as the number of PBM found at $240 \mu \mathrm{M}$ into the gel. Four separate studies were performed in each experiment. The motility of PBM incubated with whey proteins was significantly increased $(p<0.01)$. This enhancement was significantly decreased by heating or trypsinization $(p<0.01)$. tries, Inc., CA) was more than $10 \mathrm{kD}$. This was verified by Sephacryl 200 (Pharmacia) gel chromatography. Three peaks of chemokinetic activity were found that corresponded approximately to $50-60,25$, and $10-17 \mathrm{kD}$ (Fig. 3). Recombinant human TNF- $\alpha$ eluted at $50-55 \mathrm{kD}$ under identical conditions. Experiments were conducted to determine if that monokine was one of the chemokinetic agents in human milk. Direct cytotoxic effects of human milk upon murine L-929 cells were blocked by the rabbit antibodies to recombinant human TNF- $\alpha$ (Fig. 4). These same antibodies significantly decreased the chemokinetic activity of human milk whey proteins (Fig. 5) and of the fractions of milk obtained by gel filtrations (data not shown). In addition, recombinant human TNF- $\alpha$ was chemokinetic for human blood monocytes, and that effect was blocked completely by the rabbit polyclonal antibodies to recombinant human TNF- $\alpha(14 \mu / \mathrm{mi})$ (Fig. 5). We were, however, unable to demonstrate TNF- $\alpha$ in human milk by Western blotting.

We examined the possibility that the TNF- $\alpha$ effect was mediated by IL-1 activity in human milk (24) that caused the release of TNF- $\alpha$ from target cells (blood monocytes). That was done by incubating monoclonal antibodies against recombinant human IL-1 (Olympus, Lake Success, NY; $20 \mu \mathrm{g} / \mathrm{ml}$ ) with acellular milk or the protein fractions obtained by gel filtration. Monocyte activation was not blocked by anti-IL-1 (stimulation index with or without anti-IL-1, 3-5; $p>0.5$ ).

\section{DISCUSSION}

Previously, we demonstrated that HMM moved more rapidly than peripheral blood monocytes in a collagen gel system (15). In this study, we investigated the genesis of the activation of macrophages in human milk. It appeared that the enhanced motility was not due to activation of the monocytes by factors in the blood of lactating women, but to agents in human milk. Acellular milk was found to be chemokinetic for blood monocytes and the activity did not appear to be due to lipopolysaccharides because those endotoxins are quite heat stable. In contrast the chemokinetic effect of human milk was abolished by heating $\left(56^{\circ} \mathrm{C}\right.$ for $\left.20 \mathrm{~min}\right)$. The chemokinetic agents were trypsin-sensitive, acid resistant proteins whose $M_{r}$ were between $10-60 \mathrm{kD}$. Three peaks of chemokinetic activity corresponding to $50-60,25$, and $10-17 \mathrm{kD}$ were found by gel filtration. We subsequently found evidence that part of the chemokinetic activity in human milk may be due to human TNF- $\alpha$, a monokine

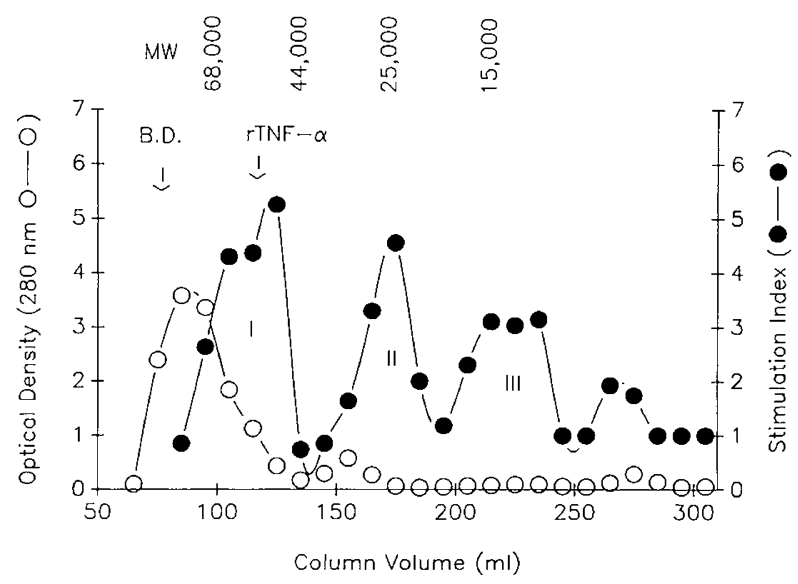

Fig. 3. The chemokinetic activity of fractions of acellular milk obtained by gel filtration on Sephacryl G-200. Chemokinetic activity was expressed as a stimulation index, i.e. a ratio between the number of monocytes at $240 \mu \mathrm{M}$ with stimulated:unstimulated blood mononuclear leukocytes. The position of blue dextran is denoted as B.D. Three peaks of chemokinetic activity were found that corresponded to proteins of $50-60,25$, and $10-17 \mathrm{kD}$. It was also found that recombinant human TNF- $\alpha$ coeluted with the highest $M_{r}$ peak $(50-60 \mathrm{kD})$. 


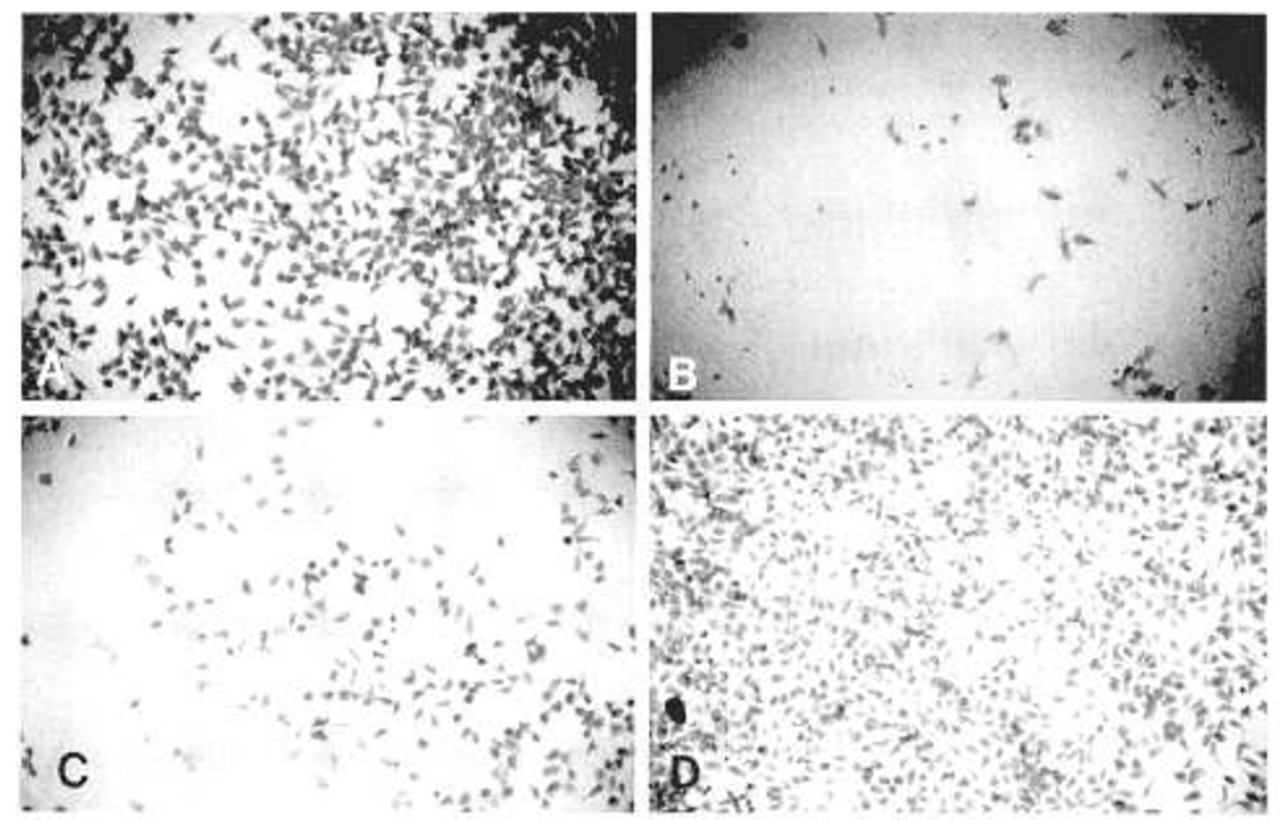

Fig. 4. Microphotographs (magnification, $160 \times$ ) of the cytotoxic effects of human milk upon murine L-929 cells. As compared to controls $(A)$, recombinant human TNF- $\alpha(B)$ or acellular human milk $(C)$ were cytotoxic and the cytotoxicity of either human recombinant TNF- $\alpha$ or acellular human milk was abolished by rabbit polyclonal antibodies to recombinant human TNF- $\alpha(D)$. In this figure, (D) depicts the effect of anti-TNF- $\alpha$ upon the cytotoxicity of acellular human milk. An entirely similar effect was found with TNF- $\alpha$ mixed with anti-TNF- $\alpha$ (illustration not shown).

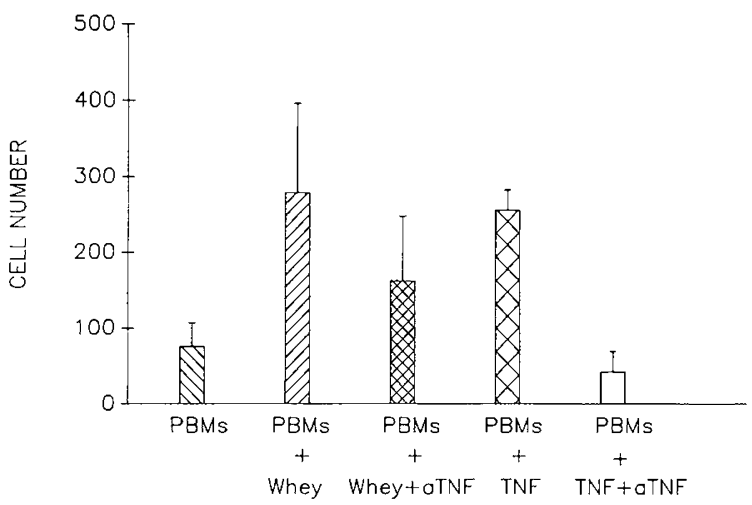

Fig. 5. The chemokinetic activity of whey proteins of human milk and recombinant human TNF- $\alpha$ and the inhibition of the chemokinetic activities of human milk or of recombinant TNF- $\alpha$ by rabbit polyclonal antibodies to recombinant human TNF- $\alpha$ (aTNF) experiments were performed. The whey proteins and recombinant human TNF- $\alpha$ were chemokinetic $(p<0.01$ for both stimuli), and those activities were partially or completely blocked by anti-TNF- $\alpha(p<0.01$ and 0.001 , respectively).

that is well known for its cytotoxic (25-30), immunomodulating (31-38), and metabolic effects (39-41). Although that monokine has not been demonstrated previously in human milk, the partial blocking of the cytotoxicity of human milk by antibodies to TNF- $\alpha$ suggested that TNF- $\alpha$, or a protein that immunologically cross-reacted with it, was present in human milk. TNF- $\alpha(41)$, along with the potential IL-1 activity in human milk (24), may account for the well known pyrogenicity of human milk. We demonstrated that part of the chemokinetic activity in human milk was also blocked by anti-TNF- $\alpha$ and that recombinant human TNF- $\alpha$ was chemokinetic for human monocytes. Thus, TNF- $\alpha$ may aid in the recruitment of monocytes.

Despite the evidence for the presence of TNF- $\alpha$ in human milk and the possibility that the 50-60 and the $10-20 \mathrm{kD}$ peaks of chemokinetic activity correspond to the trimeric and monomeric forms of TNF- $\alpha$, respectively (42), we were unable to demonstrate this monokine in human milk by Western blotting augmented by biotinylation. This may be because the concentrations of TNF- $\alpha$ in human milk are below the limits that can be detected by that method. In a companion study (Mushtaha AA, Schmalstieg FC, Hughes TK Jr, Rudloff HE, Goldman AS, unpublished data), as little as $0.7 \mathrm{pg} / \mu \mathrm{l}$ of recombinant human TNF- $\alpha$ was found to be chemokinetic. This is in keeping with a recent report that TNF- $\alpha$ is chemotactic for polymorphonuclear leukocytes and monocytes (43). Although the concommitant use of GM-colony stimulating factor in that study was a confounding variable because that agent has also been reported to be chemotactic (44), similar amounts of TNF- $\alpha$ were active in their Boyden chamber assays. It is therefore likely that only small concentrations of TNF- $\alpha$ in human milk $(\mathrm{pg} / \mu \mathrm{l})$ would be required to activate monocytes, and such small amounts of that peptide would not be detected by Western blotting.

An alternative possibility is that other activating factors in human milk stimulate the release of TNF- $\alpha$ from monocytes and that TNF- $\alpha$ was responsible for the final chemokinetic effect. This is in keeping with our observations that human IL-1 produces a chemokinetic effect through the release of TNF- $\alpha$ from monocytes (Mushtaha AA, Schmalstieg FC, Hughes TK Jr, Rudloff HE, Goldman AS, unpublished observations). Although the chemokinetic activity in human milk was not inhibited by antibodies to IL-1 and others have not found much evidence for IL-1 production or release from human milk macrophages (11), IL-1, or other agents that elicit the release of TNF- $\alpha$ from monocytes may still be present in human milk.

It is possible that TNF- $\alpha$ or other chemokinetic agents in human milk may have significant indirect or direct effects upon the recipient infant. We hypothesize that chemokinetic agents in human milk may aid in recruiting macrophages to mucosal sites of the recipient's alimentary tract $(45,46)$. It may be particularly important for the infant to receive these chemokinetic agents because of the developmental delay in the motility of blood monocytes in early life (47-50). TNF- $\alpha$ in human milk may also exert anti-viral and immunoregulatory effects by stimulating the production of interferon-B1 (36), interferon-B2 (37), and secretory component (38). This monokine also alters lipid metabolism by inhibiting lipoprotein lipase $(39,40)$. Thus, TNF- $\alpha$, the pre- 
viously reported IL-1 activity (24), or other chemokinetic agents in human milk may modulate the immunologic defenses and metabolic activities of the alimentary tract and upper airway of the recipient infant. Further studies of the characterization and the in vivo fate and functions of these molecules are planned to explore those possible effects.

Acknowledgments. We thank Kimberly $\mathrm{H}$. Palkowetz and Stanley G. Cron for their technical expertise and Susan C. Kovacevich for her secretarial assistance in the preparation of this manuscript.

\section{REFERENCES}

1. Smith CW, Goldman AS 1968 The cells of human colostrum. I. In vitro studies of morphology and function. Pediatr Res 2:103-109

2. Crago SS, Prince SJ, Pretlow TG, McGhee JR., Mestecky J 1979 Human colostral cells. I. Separation and characterization. Clin Exp Immunol 38:585597

3. Masaki M, Haywood AR 1982 Phenotype and function of human milk monocytes as antigen presenting cells. Clin Immunol Immunopathol 23:9499

4. Blau H, Paswell JH, Levanon M, Davidson J, Kohen F, Ranot B 1983 Studies on human milk macrophages: Effect of activation on phagocytosis and secretion of prostaglandin E2 and lysozyme. Pediatr Res 17:241-245

5. Cole S, Schneegerger EE, Nichtenberg NA, Cotten HR 1982 Complement biosynthesis in human breast milk macrophages and blood monocytes. Immunology 46:429-441

6. Ho PC, Lawton JWM 1978 Human colostral cells: phagocytosis and killing of E. coli and C. albicans. J Pediatr 93:910-915

7. Robinson JE, Harvey BAM, Soothill JF 1978 Phagocytosis and killing of bacteria and yeast by human milk cells after opsonization in aqueous phase of milk. Br Med J 1:1443-1445

8. Wright LL, Cody CS, Harris MC, Polin RA, Douglas SD 1982 Phagocytic and bactericidal capacity of breast milk macrophages. Pediatr Res 16 (suppl):233A (abstr)

9. Tsuda H, Takeshige K, Shibata Y, Minakami S 1984 Oxygen metabolism of human colostral macrophages: comparison with monocytes and polymorphonuclear leukocytes. J Biochem 95:1237-1245

10. Speer Ch P, Gahr M, Pabst JM 1986 Phagocytosis-associated oxidative metabolism in human milk macrophages. Acta Paediatr Scand 75:444-451

11. Subiza JL, Rodriguez C, Figueredo A, Mateos P, Alvarez R, De La Concha EG 1988 Impaired production and lack of secretion of interleukin 1 by human breast milk macrophages. J Exp Immunol 71:493-496

12. Thorpe LW, Rudloff HE, Powell LC, Goldman AS 1986 Decreased response of human milk leukocytes to chemoattractant peptides. Pediatr Res 20:373377

13. Khan AJ, Rosenfeld W, Vadapalli M, Biagton J, Khan P, Hug A, Evans HE 1980 Chemotaxis and random migration of human milk cells. $J$ Pediatr 96:879-882

14. Hawes CS, Jones WR 1985 Human milk cell migration and production of monocyte chemotactic factor: lack of activity. Pediatr Res 19:996-999

15. Özkaragöz F, Rudloff HE, Rajaraman S, Mushtaha AA, Schmalstieg FC, Goldman AS 1988 The motility of human milk macrophages in collagen gels. Pediatr Res 23:449-452

16. Goldblum RM, Garza C, Johnson CA, Nichols BL, Goldman AS 1981 Human milk banking. I. Effects of container upon immunologic factors in mature milk. Nutr Res 1:449-459

17. Böyum A 1968 Isolation of leucocytes from human blood. Further observations. Methyl cellulose, dextran, and ficoll as erythrocyte-aggregating agents. Scand J Clin Invest 21(suppl 97):31-50

18. Yam LT, Li CY, Crosby WH 1971 Cytochemical identification of monocytes and granulocytes. Am J Clin Pathol 55:283-290

19. Schor SL, Allen TD, Harrison CJ 1980 Cell migration through three-dimensional gels of native collagen fibers: Collagenase activity is not required for the migration of two permanent cell lines. J Cell Sci 46:171-186

20. Marland B 1985 Cathepsin B activity in human blood monocytes during differentiation in vitro. Scand J Immunol 22:9-16

21. Senior RM, Campbell EJ 1984 Cathepsin $G$ in human mononuclear phagocytes: comparison between monocytes and U937 monocyte-like cells. J Immunol 132:2547-2551

22. Laemmil UK 1970 Cleavage of structural proteins during the assembly of the head of bacteriophage T4. Nature (Lond) 227:680-685

23. Langford MP, Weigant DA, Georgiades JA, Johnson HM, Stanton GJ 1981 Antibody to staphyloccal enterotoxin A induced human immune interferon. J Immunol 126:1620-1623
24. Söder O 1987 Isolation of interleukin-1 from human milk. Int Arch Allergy Appl Immun 83:19-23

25. Carswell EA, Old JL, Kassel RL, Green S, Fiore N, Williamson B 1975 An endotoxin induced serum factor that causes necrosis of tumors. Proc Natl Acad Sci USA 72:3666-3670

26. Mannel DN, Moore RN, Mugenhagen SE 1980 Macrophages as a source of tumoricidal activity (tumor necrosis factor). Infect Immun 30:523-530

27. Flick DA, Giford GE 1984 Comparison of in vitro cell cytotoxic assays for tumor necrosis factor. J Immunol Methods 68:167-175

28. Feinman R, Henriksen-Destefano D, Tsujimoto M, Vilcek J 1987 Tumor necrosis factor is an important mediator of tumor cell killing by human monocytes. J Immunol 138:635-640

29. Chen J, McKinno KP, Koren HS 1985 Lipopolysaccharide (LPS) stimulates fresh human monocytes to lyse actinomycin-D-treated WEHI-164 target cells via increased secretion of a monokine similar to tumor necrosis factor. J Immunol 135:3978-3987

30. Urban JL, Shepard HM, Rothstein JL, Sugarman BJ, Schreiber H 1986 Tumor necrosis factor: a potent effector molecule for tumor cell killing by activated macrophages. Proc Natl Acad Sci USA 83:5233-5237

31. Philip R, Epstein LB 1986 Tumor necrosis factor as immunomodulator and mediator of monocyte cytotoxicity induced itself, $\gamma$-interferon and interleukin 1. Nature 323:86-89

32. Shalaby MR, Aggarwal BB, Renderknect E, Svedersky LP, Finkle BS, Palladino Jr MA 1985 Activation of human polymorphonuclear neutrophil functions by interferon-gamma and tumor necrosis factors. J Immunol 135:20692073

33. Klebanoff SJ, Vadas MA, Harlan JM, Sparks LA, Gamble JR, Agosti JM, Watersdorph AM 1986 Stimulation of neutrophils by tumor necrosis factor. J Immunol 136:4220-4225

34. Collins T, Lapierre LA, Fiers W, Strominger JL, Pober JS 1986 Recombinant human necrosis factor increases mRNA levels and surface expression of HLA-A, B antigens in vascular endothelial cells and dermal fibroblasts in vitro. Proc Natl Acad Sci USA 83:446-450

35. Chang RJ, Sang HL 1986 Effects of interferon- $\gamma$ and tumor necrosis factor on the expression of an Ia antigen on a murine macrophage cell line. J Immunol 137:2853-2856

36. Van-Damme J, de-Ley M, Van-Snick J, Dinarello CA, Billiau A 1987 The role of interferon $\mathrm{Bl}$ and the $26 \mathrm{kDa}$ protein (interferon B2) as mediators of the antiviral effects of interleukin-1 and tumor necrosis factor. J Immunol 139:1867-1872

37. Kohase M, Henriksen-DeStefano D, May LT, Viloek J, Sehgal PB 1986 Induction of beta 2 -interferon by tumor necrosis factor: a homeostatic mechanism in the control of cell proliferation. Cell 45:659-666

38. Kvala D, Lovhaug D, Sollid LM, Brandtzaeg P 1988 Tumor necrosis factor up-regulates expression of secretory component, 'the epithelial receptor for polymeric Ig'. J Immunol 140:3086-3089

39. Beutler B, Greenwald D, Hulmes JD, Chang M, Pang YC, Mathison J, Ulevitch $\mathrm{R}$, Cerami A 1985 Identity of tumor necrosis factor and the macrophagesecreted factor cachetin. Nature (Lond) 316:552-554

40. Beutler B, Mahoney J, Letrang N, Petrola P, Cerami A 1985 Purification of cachetin, a lipoprotein lipase-suppressing hormone secreted by endotoxin induced RAW264.7 cells. J Exp Med 161:984-995

41. Dinarello CA, Cannon JG, Wolff SM, Bernheim HA, Beutler B, Cerami A, Figari IS, Palladino MA Jr, O'Connor JV 1986 Tumor necrosis factor (cachectin) is an endogenous pyrogen and induces production of interleukin 1. J Exp Med 163:1433-1450

42. Wingfield $\mathrm{P}$, Pain RH, Craig S 1987 Tumor necrosis factor is a compact trimer. FEBS Letters 211:179-184

43. Ming WJ, Bersani L, Mantovani A 1987 Tumor necrosis factor is chemotactic for monocytes and polymorphonuclear leukocytes. J Immunol 138:14691474

44. Wang JM, Colella S, Allavena P, Mantovani A 1987 Chemotactic activity of human recombinant granulocyte-macrophage colony-stimulating factor. Immunology 60:439-444

45. Selby WS, Poulter LW, Hobbs S, Jewell DP, Janossy G 1983 Heterogeneity of HLA-DR-positive histiocytes in human intestinal lamina propria: a combined histochemical and immunohistological analyses. J Clin Pathol 36:379384

46. Lee S-H, Starkey PM, Gordon S 1983 Quantitative analysis of total macrophage content in adult mouse tissue. Immunochemical studies with monoclonal antibody F4/80. J Exp Med 161:475-489

47. Klein RB, Fischer TJ, Gard SE, Biberstein M, Rich KC, Stiehm ER 1977 Defective mononuclear and polymorphonuclear chemotaxis in human newborns, infants, and young children. Pediatrics 60:467-472

48. Weston WL, Carson BS, Barkin RM, Seater GD, Dusin RD, Hect SK 1977 Monocyte-macrophage function in the newborn. Am J Dis Child 131:12411242

49. Berman JD, Johnson WD Jr 1978. Monocyte function in human neonates. Infect Immun 19:898-890

50. Arenson EB, Epstein MB, Seeger RC 1979 Monocyte subsets in neonates and children. Pediatrics 64(suppl):740-744 